\title{
Change in energy metabolism of in vitro produced embryos: an alternative to make them more cryoresistant?
}

\section{Alteração no metabolismo energético de embriões produzidos in vitro: uma alternativa para torná-los mais criotolerantes?}

\author{
Luzia Renata Oliveira Dias ${ }^{1 *}$; Ivo Pivato ${ }^{2}$; Margot Alves Nunes Dode ${ }^{3}$
}

\begin{abstract}
For the development of in vitro produced (IVP) as well as in vivo produced bovine embryos, it is extremely important that their energy metabolism works properly because the embryo must be able to metabolize energy substrates that are necessary for producing energy. Lipids play an important role in early embryonic development, acting as source of energy for oocytes and embryos. However, it is known that oocytes and embryos, mainly IVP, accumulate large amounts of lipids in the cytoplasm. Although they are extremely important in embryonic development, lipids have been associated with the reduced survival of bovine embryos following cryopreservation. There is evidence that at least four different categories of lipids affect embryo survival after cryopreservation, including triglycerides (TAG), free fatty acids, cholesterol and phospholipids. Thus, many studies are being conducted to improve the resistance of IVP embryos to the cryopreservation process by reducing the concentration or removing the source of serum from the medium or by reducing oocyte/embryo lipids using mechanical or chemical means. Regarding the use of delipidating agents that reduce the uptake and synthesis of fatty acids (FA) by cells, substances such as phenazine ethosulfate (PES), forskolin, L-carnitine and isomers of conjugated linoleic acid (CLA) have been utilized. This review aims to address important issues related to embryonic energy metabolism, the importance of lipid metabolism and its relation to the cryopreservation of IVP bovine embryos by summarizing the latest research in this field.
\end{abstract}

Key words: Bovine embryos. Cryopreservation. Energy metabolism. Lipids.

\section{Resumo}

Para o desenvolvimento de embriões bovinos produzidos in vitro (PIV) e in vivo, é extremamente importante que o metabolismo energético funcione de maneira adequada, pois o embrião precisa ser capaz de metabolizar os substratos energéticos necessários para a produção de energia. Os lipídios desempenham papel importante no desenvolvimento embrionário inicial, atuando como fonte de energia para oócitos e embriões. Entretanto, sabe-se que oócitos e embriões bovinos, principalmente os PIV, acumulam grande quantidade de lipídios no citoplasma. Apesar de serem extremamente importantes no desenvolvimento embrionário, os lipídios têm sido associados com a reduzida sobrevivência após a criopreservação de embriões bovinos. Existem evidências de que pelo menos quatro classes de lipídios afetam a sobrevivência embrionária pós-criopreservação, sendo os triglicerídeos (TAG), ácidos graxos livres, colesterol e os fosfolipídios. Sendo assim, vários estudos estão sendo realizados com o intuito de melhorar a resistência dos embriões PIV ao processo de criopreservação, realizando a redução ou retirada do soro do meio ou a redução mecânica ou química de lipídios. Com relação ao uso de agentes delipidantes que diminuam a captação e síntese de ácidos graxos (AG) pelas células, substâncias como

\footnotetext{
${ }^{1}$ Discente, Universidade de Brasília, UnB, Brasília, DF, Brasil. E-mail: 1r_dias@hotmail.com

2 Prof., UnB, Brasília, DF, Brasil. E-mail: pivato@unb.br

3 Pesquisadora, Embrapa Recursos Genéticos e Biotecnologia, CENARGEN, Brasília, DF, Brasil. E-mail: margot.dode@embrapa.br * Author for correspondence
} 
fenazina etossulfato (PES), forskolin, L-carnitina e isômeros do ácido linoleico conjugado (CLA) tem sido utilizadas. O objetivo desta revisão foi abordar aspectos importantes relacionados ao metabolismo energético embrionário, a importância dos lipídios no metabolismo e sua relação com a criopreservação de embriões bovinos PIV sumarizando os estudos mais recentes nessa área.

Palavras-chave: Criopreservação. Embriões bovinos. Lipídios. Metabolismo energético.

\section{Introduction}

For the development of in vitro produced (IVP) and in vivo produced bovine embryos, it is extremely important that their energy metabolism functions properly so that they can metabolize the energy substrates necessary for the energy production that is required for their development (NELSON; COX, 2011).

However, there are differences between the metabolisms of IVP embryos and embryos produced in vivo that directly affect the response of these embryos when submitted to the cryopreservation process. IVP embryos accumulate large numbers of lipid droplets within their blastomeres, mainly from fetal calf serum (FCS) in the culture media, making these embryos more sensitive to the cryopreservation process (BARCELO-FIMBRES; SEIDEL JUNIOR, 2007; SUDANO et al., 2012).

Therefore, strategies to overcome these problems that seek better and more stable results regarding the cryopreservation of IVP embryos have been proposed, focusing mainly on two areas. The first refers to changes in cryopreservation methods, such as changes in the concentration and type of cryoprotectant, and changes in cooling times and temperatures. The other refers to the induction of modifications in embryo cells so that they become more cryotolerant, such as changes in culture conditions to minimize high lipid content (PEREIRA et al., 2007; TAKAHASHI et al., 2013; ABSALÓN-MEDINA et al., 2014; BATISTA et al., 2014; LEÃO et al., 2015). This review aims to summarize the most recent studies of changes in the cultivation system aimed at the production of better quality embryos that are more resistant to cryopreservation.

\section{Embryonic energy metabolism}

Energy metabolism undergoes changes during the stages of embryonic development. In the initial phase, the metabolism is low, and the embryos depend on oxidative phosphorylation to generate adenosine triphosphate (ATP). In this phase, it is extremely important for the embryo to metabolize its external energy reserves and substrates, as the activation of the embryonic genome in bovines occurs precisely in the 8-cell phase, thus acquiring its transcription capacity (THOMPSON, 2000; NELSON; COX, 2011).

As the embryo develops, the need for energy increases. Thus, in the stages of compaction and blastocele formation, metabolism is high, and the use of glycolysis also increases. This occurs in conjunction with an increase in protein synthesis and ion transport system activity, mainly by $\mathrm{Na}+$ / $\mathrm{K}+$ pumps, which are processes involved in the blastocele formation (LIMA; SOUZA, 2009).

The formation of ATP in the embryo, as well as in all eukaryotic cells, occurs through glycolysis and oxidative phosphorylation. During phosphorylation, a "break" of substrates, including glucose, pyruvate, amino acids and free fatty acids, which are necessary for the formation of acetyl coenzyme A (CoA), occurs. Therefore, if the demand for ATP increases, consequently, substrate consumption also increases (NELSON; COX, 2011).

Glycolysis occurs in the cytoplasm and does not require oxygen $\left(\mathrm{O}_{2}\right)$ for enzymatic metabolic reactions. For each glucose oxidization, the reaction results in lactate and four molecules of ATP. The oxidative route occurs in the mitochondria and requires oxygen. Each reaction completely oxidizes pyruvate, producing carbon dioxide $\left(\mathrm{CO}_{2}\right)$, water 
$\left(\mathrm{H}_{2} \mathrm{O}\right)$ and 32 molecules of ATP via the Krebs cycle and oxidative phosphorylation, which is the most important route of ATP formation, as approximately 93-96\% of ATP is produced during the pre-phase compaction (JOSEPH MCKEEGAN, 2015).

Despite its important role in ATP production, oxygen, as an energy substrate, can result in the formation of reactive oxygen species (ROS). ROS is an electron acceptor and can take electrons from other molecules, forming free radicals (HARVEY et al., 2002).

Between the zygote and 8-cell phases, despite the low levels of consumption, metabolism depends on glucose, oxygen and pyruvate, the latter substrate being essential for the first embryonic cleavage. Up to the 16-cell stage, glucose and pyruvate consumption remain low, but when the compaction phases in the morula and blastocyst stages begin, the consumption of these substrates increases along with oxygen consumption (SOUZA et al., 2015).

A study carried out on ovine embryos at the 8-cell stage demonstrated that the oxidation and production of $\mathrm{CO}_{2}$ and lactate was higher in IVP embryos than those produced in vivo. Regarding glucose production, although no difference was observed between the concentrations found, $\mathrm{CO}_{2}$ and lactate production was higher in the presence of $0.56 \mathrm{mmol} \mathrm{L}^{-1}$ of glucose (AZIZI-MOGHADAM, 2012). This shows that the concentration of one energetic substrate in vitro is dependent on the concentration of the other.

In the blastocyst stage, the embryo is characterized by trophectoderm (ET) cell differentiation and internal cell mass formation (ICM). Some studies have shown that the metabolic profile is different in these two types of cells, and trophectoderm consumes high levels of pyruvate and produces lactate, whereas ICM consumes more glucose (GOPICHANDRAN; LEESE, 2003). In human blastocysts, it was demonstrated that oxygen consumption in ICM and ET was identical (YAMANAKA et al., 2011). However, in rats, the
ET consumed more oxygen, which produced more ATP and presented more mitochondria than ICM. Additionally, the amount of amino acids was also significantly higher in ET (HOUGHTON, 2006).

In addition to the substrates already mentioned, amino acids are also essential for embryonic development, especially in the 8-cell and compact morula stages, when their greatest consumption occurs. In IVP embryos, the presence of bovine serum albumin (BSA) in culture media results in differences in cleavage rates, as shown by BSA replacement of polyvinyl alcohol. Additionally, the amino acid concentration is altered in the presence of BSA, as BSA can cause endocytosis in ET cells, generating lysine, leucine and glutamate, which are directly related to appropriate embryonic development (SOUZA et al., 2015).

Energy metabolism undergoes modifications depending on the way the embryo is produced. For example, it is known that in the pre- and post-compaction stages, glucose metabolism is abnormal in IVP embryos because it presents excess metabolism of this substrate through glycolysis, inhibiting oxidative phosphorylation in these embryos. This is due to the lack of a natural regulator of glycolysis, which is present in embryos produced in vivo. Therefore, the glucose metabolism in these embryos is normal (BAVISTER, 1995; GARDNER et al., 2000). Additionally, in IVP embryos, glucose metabolism increases in the presence of high $\mathrm{O}_{2}$, called aerobic glycolysis (KHURANA; NIEMANN, 2000).

Another significant metabolic change in IVP embryos is related to higher lactate production and increased oxidative rates than in vivo, suggesting higher metabolic rates in vitro. Thus, the culture conditions may induce these rates, as in vivo embryos, when exposed to extrauterine environments, showed an increase in glycolysis and $\mathrm{CO}_{2}$ production (LEESE, 2012).

The number of substrates present in the two methods of embryo production also differs. For 
example, in bovine embryos produced in vivo, less amino acid is produced than in IVP embryos (STURMEY et al., 2010).

However, energy metabolism directly interferes with embryonic development. Metabolic rates may predict embryo viability in vitro, as demonstrated by pyruvate consumption in intermediate metabolism, which is related to embryo morphological progression (GUERIF et al., 2013).

These changes in metabolism are attributed to different in vitro culture conditions during oocyte maturation and embryonic development.

\section{Problems related to metabolism}

It is worth mentioning that embryos that metabolize large amounts of glucose compromise their capacity for development. Glucose is oxidized via glycolysis or via the pentoses pathway. In the glycolytic pathway, the result of this metabolization is ATP formation, as the ATP/adenosine diphosphate (ADP) ratio is low, and the reduced nicotinamide adenine dinucleotide (NADPH)/nicotinamide adenine dinucleotide phosphate ratio (NADP) is high. During the pentose pathway, when the ATP/ $\mathrm{ADP}$ ratio is high and the NADPH/NADP ratio is low, a small amount of glucose is directed to be metabolized by this route, resulting in ribose5-phosphate, which is used in the synthesis of $\mathrm{NADPH}$, which acts in cell membrane synthesis (BEITZ, 1996; NELSON; COX, 2011).

In IVP embryos, excess glycolysis stimulation may lead to an increase in the precursors of protein and lipid synthesis, favoring the formation of intracytoplasmic lipids together with an imbalance in the reduction-oxidation state of these embryos, resulting in mitochondrial function disorder, which results in lipid accumulation (DE LA TORRESANCHEZ et al., 2006; BARCELO-FIMBRES; SEIDEL JUNIOR, 2007).

Mitochondrial dysfunction is defined as any change in the mitochondria's ability to produce sufficient ATP to meet the requirements of a cell. Mitochondria also generate ROS as a toxic byproduct in response to oxidative phosphorylation. ROS includes superoxide, hydroxide and peroxide, which are highly reactive and can cause damage as oxidative stress to organelles, lipids, proteins and deoxyribonucleic acid (DNA). However, ROS performs important cellular functions, such as in signaling pathways, calcium regulation, apoptosis, mitochondrial translocation, and metabolism. The failure of any of these functions leads to some types of cellular dysfunction (BRAND; NICHOLLS, 2011).

Another important aspect to consider is the stress that can be caused in the environment where the embryo develops, which can directly affect embryonic metabolism and cause changes in the phenotype of these embryos, resulting in abnormal growth of the fetus (LANE; GARDNER, 2004).

The embryo's response to stress has been described as the "tranquil embryo theory," which is the normal metabolic state during early embryonic development. A low metabolic rate is a predictor of viability of IVP embryos and is related to blastocyst development, which is like that observed in in vivo embryos, which are naturally "quiet" (LEESE, 2012).

Studies on bovine embryo pre-implantation related DNA damage to the amino acid profile and metabolism. The results demonstrated that the quieter the embryonic metabolism, the less susceptible they were to damage to their genome, transcriptome and proteome. In contrast, when the metabolism was more pronounced, higher levels of damage as well as greater amino acid and energy use were observed, which was aimed at the damage repair (BAUMANN et al., 2007).

Notably, several problems are related to embryonic metabolism, and once any failure occurs, the damage to the embryos may be irreversible. A balance must be struck between the energy production required for embryonic development and the speed at which that energy will be used. 
Importance of lipids in embryonic development

Lipids are broadly defined as small hydrophobic or amphipathic molecules and their major biological functions include their central role in energy storage, as structural cell membrane components and as important signaling molecules. Biological lipids are part of a group of natural molecules, including FA, eicosanoids, monoglycerides, diglycerides, triglycerides, phospholipids, sphingolipids, sterols, terpenes, prenols and fat-soluble vitamins, such as vitamins A, D, E and K (VANCE; VANCE, 2008; FAHY et al., 2009).

These biomolecules are involved in signal transduction as lipid mediators, including phosphatidylinositol, sphingolipids and eicosanoids. Additionally, they have biological functions, such as cell proliferation, migration, differentiation, pinocytosis, survival and metabolic alterations (DI PAOLO, 2006). Above all, lipids serve as signaling molecules that contribute to key events during embryonic development, implantation, and postimplantation growth (BURNUM et al., 2009).

The influence of the intracellular energy reserves generated by FA is a wide area of investigation, as most studies on energetic metabolism in embryos have focused on the use of other nutrients provided in the culture medium, such as pyruvate, glucose and amino acids (STURMEY et al., 2009).

The main class of lipids found in mammalian cell cytoplasm are triglycerides (TAGs), which are stored in the form of lipid droplets and play an important role in early embryonic development, whereby they act as a source of energy for oocytes and embryos. The cell membrane is composed mainly of phospholipids, including phosphatidylcholines, phosphatidylethanolamine and sphingomyelins, which are functional structural units of the membrane. The composition of these phospholipids determines the physicochemical properties of the membrane, including fluidity, permeability and thermal behavior. Thus, they are important substances for embryonic development
(FERGUSON; LEESE, 2006; STURMEY et al., 2009; AARDEMA et al., 2011).

The literature indicates that there is a variation in the quantity and type of TAGs that integrate the lipids of oocytes and embryos in different species. Additionally, the time between ovulation and embryo implantation determines the amount of lipids that can be stored in an embryo, as the longer this period is, the greater the need for energy, which consequently leads to greater lipid accumulation. However, it is known that bovine oocytes and embryos accumulate large amounts of lipids in the cytoplasm (STURMEY et al., 2009), mainly in IVP embryos, where the lipid droplet concentration within the blastomer is high. This is attributed to in vitro culturing with fetal calf serum (DODE et al., 2013).

Up to the 8-cell stage of fertilization, the amount of lipids remains stable. Up to the blastocyst stage, the TAG levels also remain stable, with most lipid droplets located in the ICM. Additionally, the TAG ratio may increase from the 8 -cell stage to the hatched blastocyst stage (SUDANO et al., 2012).

Although extremely important in embryonic development, lipids have been associated with reduced survival after bovine embryo cryopreservation. There is evidence that at least four classes of lipids affect post-cryopreservation embryo survival, including GAD, free fatty acids, cholesterol and phospholipids (SUDANO et al., 2013). Above all, the large accumulation of cytoplasmic droplets in bovine IVP embryos has been associated with the use of FCS in the culture medium, as this substance increases the lipid content in the embryo, either by the absorption of its lipoproteins by the embryonic cells or by the effect of $\beta$-oxidation in the mitochondria caused by an imbalance in the oxidation-reduction process (PEREIRA et al., 2007; BARCELO-FIMBRES; SEIDEL JUNIOR, 2007).

Lipid droplets are the sites where lipids are stored, and in the case of bovine embryos, TAGs 
make up the bulk of the lipids present in the cytoplasm. As required by the body, these stored lipids are used to produce energy, as membrane components and in lipid signaling. As the most important pathway for ATP production occurs in the mitochondria through the Krebs cycle and oxidative phosphorylation, any damage to this organelle can result in changes in overall lipid metabolism. There is evidence that these droplets have a protective function for cells. This has been elucidated by the fact that amphipathic molecules, which are abundant in FA, can compromise the integrity of the membrane and once transformed into TAGs, the TAGs are incorporated into the droplets, which can become innocuous. This fact can explain the large accumulation of lipid droplets in bovine IVP embryos because of the use of FCS in the culture media in vitro due to the abnormal supply of lipids contained in the serum. Thus, lipid droplets act as modulators of protein availability and lipid signaling in the nucleus (SOUZA et al., 2015).

However, the problems caused by lipids in cryopreservation are not only localized to the cytoplasm. Recent research has highlighted the fact that the phospholipid composition present in the cell membrane determines its physicochemical properties. Thus, the lipid profile of the cell membranes has been an object of study, as an increase in FA unsaturation results in increased membrane fluidity, which consequently decreases the sensitivity of IVP embryos to cryopreservation (LEÃO et al., 2015; SPRICIGO et al., 2015; SUDANO et al., 2016).

Thus, several studies are being carried out with the aim of improving the resistance of the IVP embryos to the cryopreservation process, such as modification of the in vitro culture medium, mechanical or chemical reduction of lipids and the use of agents that decrease uptake and synthesis of AG by the cells (OGAWA et al., 2010; TAKAHASHI et al., 2013; BASTISTA et al., 2014).

It is unclear what the exact FCS composition used in IVP media is, and as embryos that grow in the presence of this substance have a higher lipid content than those produced in vivo, the challenge arises to replace culture media with substances that can maintain embryonic development, such as FBS. Additionally, in regard to cryopreservation, research has been carried out that evaluated the use of substances that reduce lipid content without jeopardizing embryonic development. However, the extent to which this lipid reduction could impair embryonic development, as that these substances are essential for this development, is not yet known.

\section{Strategies for lipid content reduction in bovine} embryos

A culture medium modification using defined or semi-desiccated media without serum did not affect the blastocyst yield and increased their survival post cryopreservation (MUCCI et al., 2006; BLOCK et al., 2010; MOMOZAWA; FUKUDA, 2011). According to Sudano et al. (2011), only a reduction in the FCS concentration in the culture medium is sufficient to decrease the lipid content and increase post-cryopreservation embryo survival.

Some studies have shown that the use of phenazine ethosulfate (PES) in the post-compaction period reduces lipid accumulation and increases survival after cryopreservation in embryos. This substance promotes the balance of energetic metabolism, in addition to favoring enzymatic reactions of the pentose phosphate pathway (DE LA TORRE-SANCHEZ et al., 2006; BARCELOFIMBRES; SEIDEL JUNIOR, 2007; SUDANO et al., 2011).

The use of delipidating substances in the in vitro maturation and culture media has been widely approached, aiming to decrease the lipid content in oocytes and embryos. In the present study, the use of L-carnitine and linoleic conjugated isomers (CLA) is most commonly used in studies aimed at improving embryo quality and, consequently, greater resistance to the cryopreservation process (PEREIRA et al., 2007; TAKAHASHI et al., 2013; ABSALÓN-MEDINA et al., 2014; BATISTA et al., 2014; LEÃO et al., 2015). 
The use of forskolin has been associated with its action as an adenylate cyclase activator, which stimulates lipase, through the cAMP pathway (cyclic adenosine monophosphate), and protein kinase activity (MEN et al., 2006; CUELLO et al., 2013). Thus, supplementation with this substance in the in vitro culture medium has produced positive results regarding reduced intracytoplasmic lipids, resulting in better quality bovine embryos that overcome the damage caused by cryopreservation (SANCHES et al., 2013; PASCHOAL et al., 2014).

\section{L-Carnitine}

(L-3-Hydroxy-4-

trimethylammonium butanoate) is a soluble molecule that plays a role as a $\beta$-oxidation cofactor in lipid metabolism. It is responsible for the translocation of TAG into the mitochondria, which is metabolized in the form of CoA through $\beta$-oxidation and in the Krebs cycle and oxidative phosphorylation, resulting in ATP (SUTTONMCDOWALL et al., 2012). In the translocation, first carnitine-acyl transferase I transports the FA to the intermembrane space of the mitochondria, and then carnitine-acyl transferase II transports the same FA to the mitochondrial matrix, which then undergoes $\beta$-oxidation, as observed in Figure 1 (DUNNING; ROBKER, 2012).

In addition to acting as a delipidating agent, L-carnitine exhibits antioxidant activity, which protects cells from damage caused during cryopreservation, such as DNA damage (ABDELRAZIK et al., 2009; MINGORANCE et al., 2011). This activity reduces ROS and apoptosis (PILLICH et al., 2005; YE et al., 2010).

However, the efficiency in the use of L-carnitine depends on some factors, such as the in vitro production step, in which it is added, and the dose used. Thus, many studies demonstrated that the addition of $0.6 \mathrm{mg} \mathrm{mL}^{-1}$ to the maturation medium of porcine and bovine oocytes or in the bovine embryo culture medium was able to reduce lipid accumulation and the lipid droplet distribution (SOMFAI et al., 2011; SUTTON-MCDOWALL et al., 2012; CHANKITISAKUL et al., 2013; TAKAHASHI et al., 2013).

Figure 1. Mechanism of action of L-carnitine on lipid metabolism. In translocation, carnitine-acyl transferase I promotes the displacement of fatty acids to the intermembrane space of the mitochondria. Then, carnitine-acyl transferase II transports the same fatty acids to the mitochondrial matrix. They then undergo $\beta$-oxidation, whose product is Acetyl-CoA, which is later used in the Krebs cycle for ATP formation.

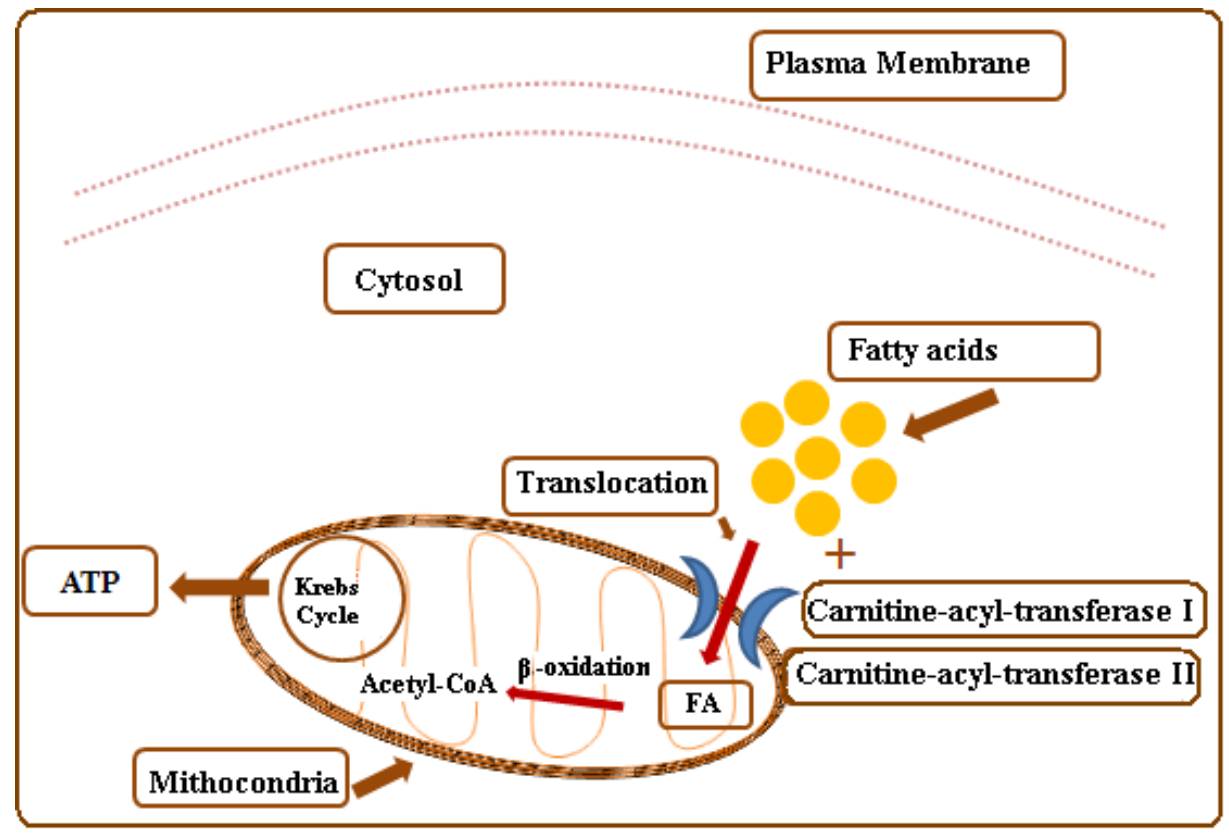


Another lipid substance that has been used to reduce lipid content in bovine embryos is CLA, more precisely, its isomers (ANDRADE et al., 2012). The trans-10, cis-12 CLA isomer has been cited for its inhibitory effect on the uptake and production of lipids by cells through their antiadipogenic properties, decreasing body fat and increasing lean mass in various animal species. This isomer reduces the expression of protein lipase (LDL) mRNA, which is located on capillary walls and is responsible for hydrolyzing extracellular TAGs and releasing FA, which allows them to be captured by the cells (Figure 2). Studies have shown that a reduction of the mRNA expression of this enzyme in different species and tissues was up to $66 \%$ and the reduced TAG amounts were up to 55\% (PARK et al., 1997, 1999; AZAIN et al., 2000; BAUMGARD et al., 2002; BROWN et al., 2003).

Another important enzyme involved in the synthesis of monounsaturated FA(FAMI) is stearoylCoA desaturase (SCD), which is responsible for the inclusion of a double bond in saturated FA, which produces FAMI during TAG synthesis. Studies have shown that trans-10, cis-12 CLA decreases SCD expression by up to $75 \%$, and inhibits its activity (LEE et al., 1998; BRETILLON et al., 1999; CHOI et al., 2000; PARK et al., 2000; BAUMGARD et al., 2002). However, other authors have shown increased mRNA expression of the same enzyme in human adipocytes cultured in the presence of this isomer (HERRMANN et al., 2009).

Although the exact mechanism by which this CLA isomer acts in fat reduction has not yet been fully elucidated, research suggests that it is due to increased energy consumption, de novo synthesis inhibition and increased FA oxidation. Additionally, as well as the specific action of CLA on adipocytes, it also decreases their size, inhibits differentiation and induces apoptosis (BRODIE et al., 1999; BAUMGARD et al., 2000; AZAIN et al., 2000; WEST et al., 2000; OHNUKI et al., 2001; EVANS et al., 2002; TERPSTRA et al., 2002). In this study, the effects of CLA on lipid metabolism depend on the type of isomer, dose and duration of supplementation (PARK et al., 1997).

Figure 2. Mechanism of action of the trans 10, cis 12 CLA isomer in lipid metabolism by reducing the expression of protein lipase (LDL) mRNA, which is responsible for hydrolyzing extracellular TAGs and releasing GA, allowing them to be captured by cells.

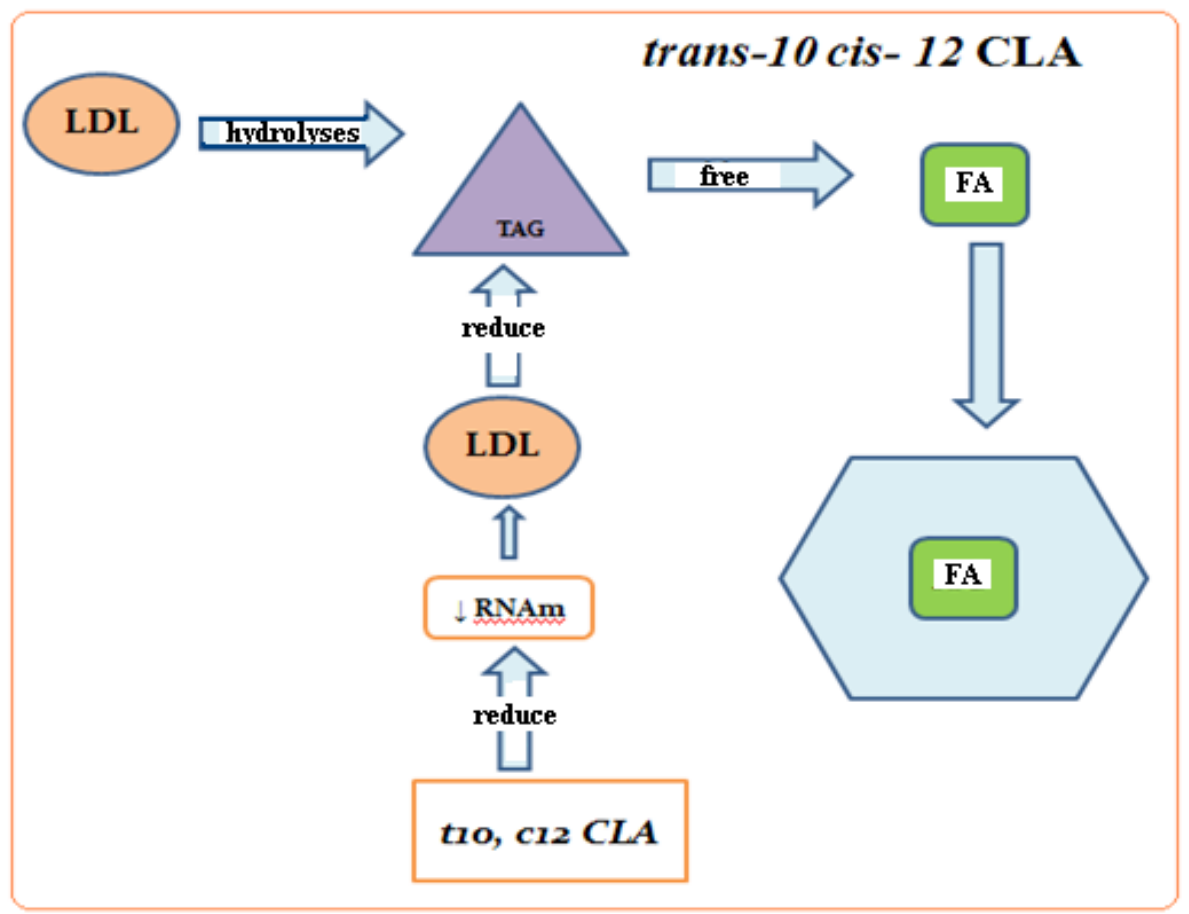


Trans-10, cis-12, affects the lipid metabolism of adipocytes, which reduces the absorption of free fatty acids without increasing lipolysis. Studies have shown that supplementation with this isomer does not improve the embryo rate in D7. However, postcryopreservation re-expansion rates were higher in bovine embryos that received supplementation with $100 \mu \mathrm{M}$ CLA during in vitro maturation or in vitro culture. Additionally, the addition of the cis9, trans-11 and trans- 10 , cis- 12 isomers at the same time also improved post-cryopreservation embryo survival (BATISTA et al., 2014; LEÃO et al., 2015). This is due to the incorporation of CLA into the lipid bilayer of the embryonic cell membrane, which increases the membrane fluidity and consequently its resistance to cryopreservation (PEREIRA et al., 2007; LEÃO et al., 2015).

Table 1 shows the most recent results obtained using substances in the IVM, IVF and/or IVC media. These studies aimed at reducing the lipid content of IVP bovine embryos, its greater cryoresistance and, consequently, better post-cryopreservation embryo development.

It is worth mentioning that in a study developed in our laboratory using L-carnitine and the trans-10, cis-12 isomer of CLA in the culture medium showed a decrease in the lipid content of the cultured embryos in the presence of L-carnitine. However, the embryo rate at day 7 was lower than that of the control group (DIAS, 2016).

Table 1. The different lipid contents used in different stages of in vitro production, D7/D8 embryo rates, lipid content or lipid profiles, re-expansion rates and references that are cited in the literature.

\begin{tabular}{|c|c|c|c|c|c|}
\hline Substance & IVP stage & Embryo rate & $\begin{array}{l}\text { Lipid content/ } \\
\text { altered profile }\end{array}$ & $\begin{array}{c}\text { Post-cryo } \\
\text { Re-expansion }\end{array}$ & Reference \\
\hline L-carnitina & IVM e/ou IVC & L-carnitina > & L-carnitina $<$ & L-carnitina > & $\begin{array}{l}\text { Takahashi et al. } \\
\text { (2013) }\end{array}$ \\
\hline L-carnitina & IVM & L-carnitina > & Not measured & without $\neq$ & $\begin{array}{l}\text { Phongnimitr et al. } \\
\text { (2013) }\end{array}$ \\
\hline L-carnitina & IVM & without $\neq$ & without $\neq$ & L-carnitina > & $\begin{array}{c}\text { Chankitisakul et al. } \\
\text { (2013) }\end{array}$ \\
\hline $\begin{array}{c}\text { CLA (trans-10 } \\
\text { cis-12) }\end{array}$ & IVC & $\mathrm{CLA}<$ & Not measured & Not measured & $\begin{array}{c}\text { Stinshoff et al. } \\
\text { (2014) }\end{array}$ \\
\hline $\begin{array}{l}\text { CLA }(\text { trans }-10 \\
\text { cis-12) }\end{array}$ & IVC & without $\neq$ & Not measured & CLA $>$ & Batista et al. (2014) \\
\hline $\begin{array}{c}\text { CLA }(\text { cis-9 } \\
\text { trans-10 e } \\
\text { trans-10 cis-12) }\end{array}$ & IVM ou IVC & $\begin{array}{c}\text { without } \neq \\
(\text { IVM) } \\
\text { CLA }<(\text { IVC }\end{array}$ & $\begin{array}{c}\text { Control < } \\
\text { CLA } 25 \mu \mathrm{M} \\
(9,11) \text { Sem } \neq\end{array}$ & $\begin{array}{c}\text { Control > } \\
\text { CLA 100 } \mu \mathrm{M} \\
(9,11) \text { IVC } \\
\text { Sem } \neq\end{array}$ & $\begin{array}{c}\text { Absálon-Medina et } \\
\text { al. (2014) }\end{array}$ \\
\hline $\begin{array}{c}\text { CLA }(\text { cis-9 } \\
\text { trans-10e } \\
\text { trans-10 cis-12) }\end{array}$ & IVM e/ou IVC & without $\neq$ & $\begin{array}{l}\text { altered lipid pro- } \\
\quad \text { file }\end{array}$ & CLA $>$ & Leão et al. (2015) \\
\hline Forskolin & IVM & without $\neq$ & Not measured & Not measured & $\begin{array}{l}\text { Paschoal et al. } \\
\qquad(2015)\end{array}$ \\
\hline
\end{tabular}




\section{Genetic markers related to lipid metabolism}

Gene expression analysis contributes significantly to the evaluation of embryonic quality at the different stages of embryo development and various events that occur during embryonic development. Additionally, many studies have been carried out to identify genes of interest, according to the literature of the field (OROZCO-LUCERO et al., 2014; SPRICIGO et al., 2014; LEME et al., 2016). In the case of IVP bovine embryos, it is known that the expression of genes important for embryonic development is different from those produced in vivo (MUNDIM et al., 2009). For detailed study of these differences related to molecular aspects in vitro and in vivo, the bovine transcriptome has been used (CLEMENTE et al., 2011).

Thus, the evaluation of the expression of genes related to lipid metabolism has been performed to predict the ability of embryos to respond to different treatments during maturation and in vitro culture, such as the use of substances that can generate positive responses to the resistance of IVP embryos to the cryopreservation process (TAKAHASHI et al., 2013; BATISTA et al., 2014; GHANEM et al., 2014; BALDOCEDA et al., 2015). Among these studies, the CPT2 gene was cited for generating carnitine palmitoyltransferase 2 formation, which is essential for the FA oxidation that occurs inside the mitochondria. Carnitine binds to long chain FAs that are translocated into the mitochondria. After this process, the enzyme in question removes the carnitine and adds the acetyl CoA, with consequent energy production (DUNNING; ROBKER, 2012).

A study evaluated the effects of two lipid metabolism regulators, L-carnitine and PES, on the embryonic development of IVP embryos in the expression of genes regulating lipid metabolism. The results showed that the relative abundance of CPT2 mRNA was increased in embryos cultured in the presence of L-carnitine and PES when compared with the control group (GHANEM et al., 2014).
In another transcriptome study, bovine embryos were submitted to L-carnitine treatment during in vitro culture to observe the effect of this substance on different lipid levels and mitochondrial activity. However, CPT2 expression with and without L-carnitine treatment did not differ (BALDOCEDA et al., 2015).

Acyl CoA expression: Diacylglycerol acyltransferase 2 (DGAT2) has also been reported in IVP embryos. This membrane protein catalyzes TAG synthesis through the diacylglycerol and AGCoA substrates and is present in the endoplasmic reticulum. However, when cells are incubated with FA, this protein interacts with lipid droplets to catalyze the synthesis of TAG and thus to expand such droplets. It has been shown that DGAT2 interacts with proteins that synthesize the AG-CoA substrate. Additionally, the use of disuccinimidyl suberate (DSS) as a cross-linking agent has demonstrated that DGTA2 is part of a protein complex in both lipid and droplet membranes (JIN et al., 2014).

In mammalian somatic cells, various proteins are involved in lipid droplet formation, including the enzymes, DGAT1 and DGAT2 (HARRIS et al., 2011). In a study by Ghanem et al. (2014), the regulatory genes of these lipid droplet-forming enzymes were down-regulated in embryos supplemented with L-carnitine and PES compared with the control group. This result demonstrated that these genes are promising candidates as biomarkers of lipid content in bovine IVP embryos.

Another gene related to the formation of lipid droplets is PLIN2, which encodes a protein belonging to the perilipin family that is responsible for the intracellular coating of lipid droplets. This protein is related to the surface membrane material of the lipid globule and possibly to the development and maintenance of adipose tissue. Additionally, it can be found in cultured cell lines, including fibroblasts, endothelial cells, epithelial cells, Sertoli cells, Leydig cells, and hepatocytes in the liver 
and in tissues such as the mammary gland and adrenal cortex. PLIN2 is responsible for limiting interactions between lipases and the neutral lipids of the droplets, resulting in lipid accumulation and increasing the number and size of lipid droplets in the cell. Thus, its identification may serve as a marker of lipid accumulation (BICKEL et al., 2009).

The first expression analysis of the PLIN2 and PLIN3 proteins in in vitro maturation and initial embryonic development in cattle was performed by Sastre et al. (2014). The study demonstrated that PLIN2 expression was not altered after in vitro maturation but that PLIN3 was down-regulated. Regarding embryo development, PLIN2 and PLIN3 expression increased considerably until the morula and blastocyst stages, respectively. This coincided with increased lipid droplet numbers from the twocell to the blastocyst stage in IVP embryos (LEROY et al., 2005).

In a study by Ghanem et al. (2014), PLIN2 expression in bovine IVP embryos was also evaluated in the presence of L-carnitine and PES. The expression was down-regulated in embryos supplemented with substances compared with the control group, which associated the gene with lipid droplet formation.

PLIN2 expression was also evaluated in murine oocytes. The results showed that the expression of this gene was higher in murine COCs matured in lipid-rich follicular fluid than in mature follicular cells (YANG et al., 2012).

As several articles have shown, the use of gene expression analysis may predict the use of potential lipid accumulation biomarkers and, consequently, post-cryopreservation embryonic quality. Additionally, all genes mentioned above were altered after the use of substances that were proposed to alter lipid metabolism.

\section{Genetic markers of energy metabolism}

Regarding substrates used in the energy formation process for embryo development, glucose is of extreme importance and the literature has cited theSLC2A4 gene, which encodes a glucose transporter protein 4 (GLUT4) that is one of the main glucose carriers. This protein is highly expressed in adipose tissue and skeletal muscle, and it exhibits a unique characteristic of dynamism in its intracellular arrangement. Moreover, it is well distributed in the cytoplasm in the non-stimulated state, and it is redirected to the plasma membrane in response to insulin and other stimuli. GLUT4 contains unique sequences in its $\mathrm{N}$-terminal cytoplasmic domain and carboxylic acids $(\mathrm{COOH})$, which direct its characteristic membrane transport capacity (HUANG; CZECH, 2007). In cattle, GLUT4 has been detected in the pre-implantation period of embryonic development (SANTOS et al., 2000).

The oxidative stress repair system consists of a defense system of the cell by means of antioxidants. It is induced when any substance is present in low concentrations in relation to a oxidizable substrate, and it slows or inhibits the oxidation of these substrates. The manganese superoxide dismutase gene (MnSOD) encodes an antioxidant enzyme (SOD2) that in turn protects cells from oxidative damage. It transforms two molecules of superoxide anion into water and hydrogen peroxide, which protects the mitochondria from superoxide release as a product of respiration; therefore, it is the primary defense of cells against damage by free radicals (MUNDIM, 2008).

The production of free radicals has pronounced effects on DNA, RNA and protein synthesis. This process, which is considered physiological, can also alter the cell membrane, increase intracellular $\mathrm{pH}$ and interfere with mitochondrial function (LEME, 2008). Excess free radicals can cause cell damage leading to oxidative stress and delayed embryonic development, and they can cause metabolic dysfunction and even accelerate and increase apoptosis (GUÉRIN et al., 2001), which can generate a poor or unviable embryo (RIZOS et al., 2002; MUNDIM et al., 2009). 
A study evaluated the effect of in vitro culture systems using low and high voltage $\mathrm{O} 2$, and it indicated that MnSOD gene expression was more abundant in embryos that were cultured in a system using high $\mathrm{O}_{2}$ voltage (CORRÊA et al., 2008).

\section{Final Considerations}

Several alternatives to improve the cryotolerance of IVP bovine embryos that aim primarily to lower lipid content and improve embryo quality are available. This can be done by changing the culture medium, such substitution and/or withdrawal of FBS or the use of delipidating substances. Notably, according to the literature, both strategies can be used successfully to increase the resistance of IVP embryos to the cryopreservation process. However, it should be noted that when lipid substances are used, the amount of lipids that can be removed from embryos without impairing post-hatching development is not known. Therefore, as lipids are important sources of energy for embryonic development, it is more convenient to use FBS withdrawal from the IVP media and its substitution with BSA, for example, or another synthetic substance, to avoid possible metabolism energy changes in IVP embryos, thus allowing for adequate post-hatching embryo development.

\section{References}

AARDEMA, H.; VOS, P. L. A. M.; LOLICATO, F.; ROELEN, B. A. J.; KNIJN, H. M.; VAANDRAGER, A. B.; HELMS, J. B.; GADELLA, B. M. Oleic acid prevents detrimental effects of saturated fatty acids on bovine oocyte developmental competence. Biology of Reproduction, Champaign, v. 85, n. 1, p. 62-69, 2011.

ABDELRAZIK, H.; SHARMA, R.; MAHFOUZ, R.; AGARWAL, A. L-carnitine decreases DNA damage and improves the in vitro blastocyst development rate in mouse embryos. Fertility and Sterility, Birmingham, v. 91, n. 2, p. 589-596, 2009.

ABSALÓN-MEDINA, V. A.; BEDFORD-GUAUS, S. J.; GILBERT, R. O.; SIQUEIRA, L. C.; ESPOSITO, G.; SCHNEIDER, A.; CHEONG, S. H.; BUTLER, W.
$\mathrm{R}$. The effects of conjugated linoleic acid isomers cis9,trans-11 and trans-10,cis-12 on in vitro bovine embryo production and cryopreservation. Journal of Dairy Science, Champaign, v. 97, n. 10, p. 6164-6176, 2014.

ANDRADE, J. C.; ASCENÇÃO, K.; GULLÓN, P.; HENRIQUES, S. M. S.; PINTO, J. M. S.; ROCHASANTOS, T. A. P.; FREITAS, A. C.; GOMES, A. M. Production of conjugated linoleic acid by food-grade bacteria: A review. International Journal of Dairy Technology, Huntingdon, v. 65, n. 4, p. 467-481, 2012.

AZAIN, M.; HAUSMAN, D.; SISK, M.; FLATT, W.; JEWELL, D. Dietary conjugated linoleic acid reduces rat adipose tissue cell size rather than cell number. The Journal of Nutrition, Rockville, v. 130, n. 3, p. 15481554, 2000.

AZIZI-MOGHADAM, A. Metabolism of energy substrates of in vitro and in vivo derived embryos from ewes synchronized and super ovulated with norgestomet and porcine follicle stimulating hormone. Journal of Animal Science and Biotechnology, London, v. 3, n. 1, p. 3-37, 2012.

BALDOCEDA, L.; GAGNÉ, A. D.; FERREIRA, C. R.; ROBERT, A. C. Genetic influence on the reduction in bovine embryo lipid content by L-carnitine. Reproduction, Fertility and Development, Melbourne, v. 28, n. 8, p. 1172-1184, 2015.

BARCELO-FIMBRES, M.; SEIDEL JUNIOR, G. E. Effects of either glucose or fructose and metabolic regulators on bovine embryo development and lipid accumulation in vitro. Molecular Reproduction and Development, New York, v. 74, n. 11, p. 1406-1418, 2007.

BATISTA, R. I. T. P.; RAPOSO, N. R. B.; CAMPOSJUNIOR, P. H. A.; PEREIRA, M. M.; CAMARGO, L. S. A.; CARVALHO, B. C.; GAMA, M. A. S.; VIANA, J. H. M. Trans-10, cis-12 conjugated linoleic acid reduces neutral lipid content and may affect cryotolerance of in vitro-produced crossbred bovine embryos. Journal of Animal Science and Biotechnology, London, v. 5, n. 33, p. 1-8, 2014.

BAUMANN, C. G.; MORRIS, D. G.; SREENAN, J. M.; LEESE, H. J. The quiet embryo hypothesis: molecular characteristics favoring viability. Molecular Reproduction and Development, New York, v. 74, n. 10, p. 1345-1353, 2007.

BAUMGARD, L. H.; CORL, B. A.; DWYER, D. A.; SAEBØ, A.; BAUMAN, D. E. Identification of the conjugated linoleic acid isomer that inhibits milk fat synthesis. American Journal of Physiology. Regulatory Integrative and Comparative Physiology, Bethesda, v. 278, n. 1, p. 179-184, 2000. 
BAUMGARD, L. H.; MATITASHVILI, E.; CORL, B. A.; DWYER, D. A.; BAUMAN, D. E. Trans-10, cis-12 conjugated linoleic acid decreases lipogenic rates and expression of genes involved in milk lipid synthesis in dairy cows. Journal of Dairy Science, Champaign, v. 85, n. 9, p. 2155-2163, 2002.

BAVISTER, B. D. Culture of preimplantation embryos: facts and artefacts. Human Reproduction Update, Oxford, v. 1, n. 2, p. 91-148, 1995.

BEITZ, D. C. Metabolismo dos carboidratos; metabolismo dos lipídios. In: SWENSON, M. J.; REECE, W. O. Dukes fisiologia dos animais domésticos. Rio de Janeiro: Guanabara Koogan, 1996. p. 398-429.

BICKEL, P. E.; TANSEY, J. T.; WELTE, M. A. PAT proteins, an ancient family of lipid droplet proteins that regulate cellular lipid stores. Biochimica et Biophysica Acta, Amsterdam, v. 1791, n. 6, p. 419-440, 2009.

BLOCK, J.; BONILLA, L.; HANSEN, P. J. Efficacy of in vitro embryo transfer in lactating dairy cows using fresh or vitrified embryos produced in a novel embryo culture medium. Journal Dairy Science, Champaign, v. 93, n. 11, p. 5234-5242, 2010.

BRAND, M. D.; NICHOLLS, D. G. Assessing mitochondrial dysfunction in cells. The Biochemical Journal, London, v. 435, n. 2, p. 297-312, 2011.

BRETILLON, L.; CHARDIGNY, J. M.; GRÉGOIRE, S.; BERDEAUX, O.; SÉBÉDIO, J. L. Effects of conjugated linoleic acid isomers on the hepatic microsomal desaturation activities in vitro. Lipids, Champaign, v. 34, n. 9, p. 965-969, 1999.

BRODIE, A. E.; MANNING, V. A.; FERGUSON, K. R.; JEWELL, D. E.; HU, C. Y. Conjugated linoleic acid inhibits differentiation of pre- and postconfluent 3T3L1 preadipocytes but inhibits cell proliferation only in preconfluent cells. The Journal of Nutrition, Rockville, v. 129, n. 3, p. 602-606, 1999.

BROWN, J. M.; BOYSEN, M. S.; JENSEN, S. S.; MORRISON, R. F.; STORKSON, J.; LEA-CURRIE, R.; PARIZA, M.; MANDRUP, S.; McINTOSH, M. K. Isomer-specific regulation of metabolism and PPAR $\gamma$ signaling by CLA in human preadipocytes. Journal of Lipid Research, Bethesda, v. 44, n. 7, p. 1287-1300, 2003.

BURNUM, K. E.; CORNETT, D. S.; PUOLITAIVAL, S. M.; MILNE, S. B.; MYERS, D. S.; TRANGUCH, S.; BROWN, H. A.; DEY, S. K.; CAPRIOLI, R. M. Spatial and temporal alterations of phospholipids determined by mass spectrometry during mouse embryo implantation. Journal of Lipid Research, Bethesda, v. 50, n. 11, p. 2290-2298, 2009.
CHANKITISAKUL, V.; SOMFAI, T.; INABA, Y.; TECHAKUMPHU, M.; NAGAI, T. Supplementation of maturation medium with L-carnitine improves cryo-tolerance of bovine in vitro matured oocytes. Theriogenology, Stoneham, v. 79, n. 4, p. 590-598, 2013.

CHOI, Y.; KIM, Y. C.; HAN, Y. B.; PARK, Y.; PARIZA, M. W.; NTAMBI, J. M. The trans-10,cis-12 isomer of conjugated linoleic acid downregulates stearoyl-CoA desaturase 1 gene expression in 3T3-L1 adipocytes. The Journal of Nutrition, Rockville, v. 130, n. 8, p. 19201924, 2000.

CLEMENTE, M.; LOPEZ-VIDRIERO, I.; O'GAORA, P.; MEHTA, J. P.; FORDE, N.; GUTIERREZ-ADAN, A.; LONERGAN, P.; RIZOS, D. Transcriptome changes at the initiation of elongation in the bovine conceptus. Biology of Reproduction, Champaign, v. 85, n. 2, p. 285295, 2011.

CORREAA, G. A.; RUMPF, R.; MUNDIM, T. C.; FRANCO, M. M.; DODE, M. A. Oxygen tension during in vitro culture of bovine embryos: effect in production and expression of genes related to oxidative stress. Animal Reproduction Science, Amsterdam, v. 104, n. 2-4, p. 132-142, 2008.

CUELLO, C. G. J.; SANCHEZ-OSORIO, J.; GIL, M. A.; PARRILLA, I.; ANGEL, M. A.; VAZQUEZ, J. M.; ROCA, J.; MARTINEZ, E. A. Forskolin improves the cryosurvival of in vivo-derived porcine embryos at very early stages using two vitrification methods. Cryobiology, San Diego, v. 66, n. 2, p. 144-150, 2013.

DE LA TORRE-SANCHEZ, J. F.; GARDNER, D. K.; PRIEIS, K.; GIBBONS, J.; SEIDEL JUNIOR, G. E. Metabolic regulation of in vitro produced bovine embryos. II. Effects of phenazine ethosulfate, sodium azide and 2,4-dinitrophenol during postcompactation development on glucose metabolism and lipid accumulation. Reproduction, Fertility and Development, Melbourne, v. 18, n. 5, p. 597-607, 2006.

DI PAOLO, G.; DE CAMILLI, P. Phosphoinositides in cell regulation and membrane dynamics. Nature, London, v. 443, n. 7112, p. 651-657, 2006.

DIAS, L. R. O. Efeito de agentes delipidantes durante o cultivo no desenvolvimento embrionário e conteúdo lipídico de embriões bovines produzidos in vitro. 2016. Dissertação (Mestrado em Ciências Animais) Universidade de Brasília, Faculdade de Agronomia e Medicina Veterinária, Brasília.

DODE, M. A. N.; LEME, L. O.; SPRÍCIGO, J. F. W. Criopreservação de embriões bovinos produzidos in vito. Revista Brasileira de Reprodução Animal, Belo Horizonte, v. 37, n. 2, p. 145-150, 2013. 
DUNNING, K. R.; ROBKER, L. R. Promoting lipid utilization with L-carnitine to improve oocyte quality. Animal Reproduction Science, Amsterdam, v. 134, n. 1-2, p. 69-75, 2012.

EVANS, M.; LIN, X.; ODLE, J. McINTOSH. Trans-10, cis-12 conjugated linoleic acid increases fatty acid oxidation in 3T3-L1 preadipocytes. The Journal of Nutrition, Rockville, v. 132, n. 3, p. 450-455, 2002.

FAHY, E.; SUBRAMANIAM, S.; MURPHY, R.; NISHIJIMA, M.; RAETZ, C.; SHIMIZU, T.; SPENER, F.; VAN MEER, G.; WAKELAM, M.; DENNIS, E. A. Update of the LIPID MAPS comprehensive classification system for lipids. Journal of Lipid Research, Bethesda, v. 50, p. 9-14, 2009. Suplemento.

FERGUSON, E. M. E.; LEESE, H. J. A potential role for triglyceride as an energy source during bovine oocyte maturation and early embryo development. Molecular Reproduction and Development, New York, v. 73, n. 9, p. 1195-1201, 2006.

GARDNER, D. K.; POOL, T. B.; LANE, M. Embryo nutrition and energy metabolism and its relationship to embryo growth, differentiation and viability. Seminars in Reproductive Medicine, San Francisco, v. 18, n. 2, p. 205-218, 2000.

GHANEM, N.; HA, A. N.; FAKRUZZAMAN, M. D.; BANG, J. I.; LEE, S. C.; KONG, I. K. Differential expression of selected candidate genes in bovine embryos produced in vitro and cultured with chemicals modulating lipid metabolism. Theriogenology, Stoneham, v. 82, n. 2, p. 1-13, 2014.

GOPICHANDRAN, N.; LEESE, H. J. Metabolic characterization of the bovine blastocyst, inner cell mass, trophectoderm and blastocoel fluid. Reproduction, Cambridge, v. 126, n. 3, p. 299-308, 2003.

GUERIF, F.; MCKEEGAN, P.; LEESE, H. J.; STURMEY, R. G. A simple approach for COnsumption and RElease (CORE) analysis of metabolic activity in single mammalian embryos. PLoS One, San Francisco, v. 8 , n. 8 , p. 1-9, 2013.

GUÉRIN, P.; EL MOUATASSIM, S.; MENEZO, $\mathrm{Y}$. Oxidative stress and protection against reactive oxygen species in the pre-implantation embryo and its surroundings. Human Reproduction Update, Oxford, v. 7, n. 2, p. 175-189, 2001.

HARRIS, C. A.; RYAN, J. T.; STREEPER, S.; STONE, S. J.; KUMARI, M.; YANG, K.; HAN, X.; BROWNELL, N.; GROSS, R. W.; ZECHNER, R.; FARESE JUNIOR, R. V. DGAT enzymes are required for triacylglycerol synthesis and lipid droplets in adipocytes. Journal of Lipid Research, Bethesda, v. 52, n. 4, p. 657-667, 2011.
HARVEY, A. J.; KIND, K. L.; THOMPSON, J. G. REDOX regulation of early embryo development. Reproduction, Cambridge, v. 123, n. 4, p. 479-486, 2002.

HERRMANN， J.; RUBIN， D.; HÄSLER， R.; HELWIG, U.; PFEUFFER, M.; AUINGER, A.; LAUE, C.; WINKLER, P.; SCHREIBER, S.; BELL, D.; SCHREZENMEIR, J. Isomerspecific effects of CLA on gene expression in human adipose tissue depending on PPAR $\gamma 2$ P12A polymorphism: a double blind, randomized, controlled cross-over study. Lipids in Health and Disease, London, v. 8, n. 35, p. 35-47, 2009.

HOUGHTON, F. D. Energy metabolism of the inner cell mass and trophectoderm of the mouse blastocyst. Differentiation, London, v. 74, n. 1, p. 11-18, 2006.

HUANG, S.; CZECH, M. P. The GLUT4 Glucose Transporter. Cell Metabolism, Berkeley, v. 5, n. 4, p. 237-252, 2007. JIN, Y.; MCFIE, P. J.; BANMAN, S. L.; BRANDT, C.; STONE, S. J. Diacylglycerol Acyltransferase-2 (DGAT2) and Monoacylglycerol Acyltransferase-2 (MGAT2) interact to promote triacylglycerol synthesis. The Journal of Biological Chemistry, Bethesda, v. 289, n. 41, p. 28237-28248, 2014.

JOSEPH MCKEEGAN, P. Metabolic regulation during early embryo development. 2015. Thesis (PhD) (Doutorado em nome do Curso) - Hull York Medical School, The University of Hull and the University of York, Heslington. KHURANA, N. K.; NIEMANN, H. Energy metabolism in preimplantation bovine embryos derived in vitro or in vivo. Biology of Reproduction, Champaign, v. 62, n. 4, p. 847-856, 2000.

LANE, M.; GARDNER, D. K. Understanding cellular disruptions during early embryo development that perturb viability and fetal development. Reproduction, Fertility, and Development, Melbourne, v. 17, n. 3, p. 371-378, 2004.

LEÃO, B. C. S.; ROCHA-FRIGONI, N. A. S.; CABRAL, E. C.; COELHO, M. B.; FERREIRA, C. R.; EBERLIN, M. N.; ACCORSI, M. F.; NOGUEIRA, É.; MINGOTI, G. Z. Improved embryonic cryosurvival observed after in vitro supplementation with conjugated linoleic acid is related to changes in the membrane lipid profile. Theriogenology, Stoneham, v. 84, n. 1, p. 127-136, 2015.

LEE, K. N.; PARIZA, M. W.; NTAMBI, J. M. Conjugated linoleic acid decreases hepatic stearoyl-CoA desaturase mRNA expression. Biochemical and Biophysical Research Communications, Orlando, v. 248, n. 3, p. 817821, 1998.

LEESE, H. J. Metabolism of the preimplantation embryo: 40 years on. Reproduction, Cambridge, v. 143, n. 4, p. 417-427, 2012. 
LEME, L. O. Efeito de diferentes fontes proteicas na qualidade e quantidade de embriões bovinos produzidos in vitro. 2008. Dissertação (Mestrado em Ciências Agrárias) - Universidade de Brasília. Faculdade de Agronomia e Medicina Veterinária, Brasília.

LEME, O. L.; DUFORT, I.; SPRICIGO, J. F. W.; BRAGA, T. F.; SIRARD, M. A.; FRANCO, M. M.; DODE, M. A. N. Effect of vitrification using the Cryotop method on the gene expression profile of in vitro-produced bovine embryos. Theriogenology, Stoneham, v. 85, n. 2, p. 724733, 2016.

LEROY, J. L.; GENICOT, G.; DONNAY, I.; VAN SOOM, A. Evaluation of the lipid content in bovine oocytes and embryos with nile red: a practical approach. Reproduction in Domestic Animals, Berlin, v. 40, n. 1, p. 76-78, 2005.

LIMA, I. M. T.; SOUZA, A. L. Desenvolvimento e sobrevivência de embriões no período de préimplantação: enfoque em ruminantes. Revista Brasileira de Reprodução Animal, Belo Horizonte, v. 33, n. 4, p. 194-202, 2009.

MEN, H.; AGCA, Y.; RILEY, L. K.; CRITSER, J. K. Improved survival of vitrified porcine embryos after partial delipation through chemically stimulated lipolysis and inhibition of apoptosis. Theriogenology, Stoneham, v. 66, n. 8 , p. 2008-2016, 2006.

MINGORANCE, C.; RODRIGUEZ-RODRIGUEZ, R.; JUSTO, M. L.; HERRERA, M. D.; SOTOMAYOR, M. A. de. Pharmacological effects and clinical applications of propionyl-l-carnitine. Nutrition Reviews, New York, v. 69, n. 5, p. 279-290, 2011.

MOMOZAWA, K.; FUKUDA, Y. Establishment of an advanced chemically defined medium for early embryos derived from in vitro matured and fertilized bovine oocytes. Journal of Reproduction and Development, Tokyo, v. 57, n. 6, p. 681-689, 2011.

MUCCI, N.; ALLER, J.; KAISER, G. G.; HOZBOR, F.; CABODEVILA, J.; ALBERIO, R. H. Effect of estrous cow serum during bovine embryo culture on blastocyst development and cryotolerance after slow freezing or vitrification. Theriogenology, Stoneham, v. 65, n. 8, p. 1551-1562, 2006.

MUNDIM, T. C.; RAMOS, A. F.; SARTORI, R.; DODE, M. A.; MELO, E. O.; GOMES, L. F.; RUMPF, R.; FRANCO, M. M. Changes in gene expression profiles of bovine embryos produced in vitro, by natural ovulation, or hormonal superstimulation. Genetics and Molecular Research, Alto da Boa Vista, v. 8, n. 4, p. 1398-1407, 2009.
MUNDIM, T. C. D. Estudos de genes candidatos associados ao desenvolvimento embrionário bovinos em diferentes sistemas de produção de embriões. 2008. Mestrado (Dissertação em Ciências Animais) - Faculdade de Agronomia e Medicina Veterinária, Universidade de Brasília, Brasília.

NELSON, D. L.; COX, M. M. Princípios de bioquímica de Lehninger. 5. ed. Porto Alegre: Artmed, 2011. 1304 p.

OGAWA, B. S.; NAKAYAMA, N.; MATSUNARI, H.; NAKANO, K.; FUJIWARA, T.; IKEZAWA, Y.; NAGASHIMA, H. Developmental ability of porcine in vitro matured oocytes at the meiosis II stage after vitrification. Journal of Reproduction and Development, Tokyo, v. 56, n. 3, p. 356-361, 2010.

OHNUKI, K.; HARAMIZU, S.; OKI, K.; ISHIHARA, K.; FUSHIKI, T. A single oral administration of conjugated linoleic acid enhanced energy metabolism in mice. Lipids, Champaign, v. 36, n. 6, p. 583-587, 2001.

OROZCO-LUCERO, E.; DUFORT, I.; ROBERT, C.; SIRARD, M. Rapidly cleaving bovine two-cell embryos have better developmental potential and a distinctive mRNA pattern. Molecular Reproduction and Development, New York, v. 81, n. 1, p. 31-41, 2014.

PARK, Y.; ALBRIGHT, K. J.; LIU, W.; STORKSON, J. M.; COOK, M. E.; PARIZA, M. W. Effect of conjugated linoleic acid on body composition in mice. Lipids, Champaign, v. 32, n. 8, p. 853-858, 1997.

PARK, Y.; STORKSON, J. M.; ALBRIGHT, K. J.; LIU, W.; PARIZA, M. W. Evidence that the trans-10,cis-12 isomer of conjugated linoleic acid induces body composition changes in mice. Lipids, Champaign, v. 34, n. 3, p. 235-241, 1999.

PARK, Y.; STORKSON, J. M.; NTAMBI, J. M.; COOK, M. E.; SIH, C. J.; PARIZA, M. W. Inhibition of hepatic stearoyl-CoA desaturase activity by trans-10,cis- 12 conjugated linoleic acid and its derivatives. Biochimica et Biophysica Acta, Amsterdam, v. 1486, n. 2-3, p. 285292, 2000.

PASCHOAL, D. M.; MAZIERO, R. R. D.; SUDANO, M. J.; GUASTALI, M. D.; VERGARA, L. E.; CROCOMO, L. F.; LIMA-NETO, J. F.; MAGALHAES, L. C. O.; MONTEIRO, B. A.; RASCADO, T. S.; MARTINS JR, A.; LEAL. C. L. V.; LANDIM-ALVARENGA, F. C. In vitro embryos production after oocytes treatment with forskolin. Zygote, Cambridge, v. 24, n. 2, p. 161-171, 2015. 
PASCHOAL, D. M.; SUDANO, M. J.; GUASTALI, M. D.; MAZIERO, R. R. D.; CROCOMO, L. F.; MAGALHAES, L. C. O.; RASCADO, T. S.; MARTINS, A.; LANDIM-ALVARENGA, F. C. Forskolin effect on the cryosurvival of in vitro-produced bovine embryos in the presence or absence of fetal calf serum. Zygote, Cambridge, v. 22, n. 2, p. 146-157, 2014.

PEREIRA, R. M.; BAPTISTA, M. C.; VASQUES, M. I.; HORTA, A. E. M.; PORTUGAL, P. V.; BESSA, R. J. B.; CHAGAS E SILVA, J.; SILVA PEREIRA, M.; MARQUES, C. C. Cryo-survival of bovine blastocysts is enhanced by culture with trans-10 cis-12 conjugated linoleic acid (10t, 12c CLA). Animal Reproduction Science, Amsterdam, v. 98, n. 3-4, p. 293-301, 2007.

PILliCH, R. T.; SCARSELLA, G.; RISULEO, G. Reduction of apoptosis through the mitochondrial pathway by the administration of acetyl-L-carnitine to mouse fibroblasts in culture. Experimental Cell Research, New York, v. 306, n. 1, p. 1-8, 2005.

PHONGNIMITR, T.; LIANG, Y.; SRIRATTANA, K.; PANYAWAI, K.; SRIPUNYA, N.; TREETAMPINICH, C.; PARNPAI, R. Effect of L-carnitine on maturation, cryo-tolerance and embryo developmental competence of bovine oocytes. Animal science journal, Tokyo, v. 84, n. 11, p. 719-725, 2013.

RIZOS, D.; WARD, F.; DUFFY, P.; BOLAND, M. P.; LONERGAN, P. Consequences of bovine oocyte maturation, fertilization or early embryo development in vitro versus in vivo: implications for blastocyst yield and blastocyst quality. Molecular Reproduction and Development, New York, v. 61, n. 2, p. 234-248, 2002.

SANCHES, B. V.; MARINHO, L. S. R.; FILHO, B. D. O.; PONTES, J. H. F.; BASSO, A. C.; MEIRINHOS, M. L. G.; SILVA-SANTOS, K. C.; FERREIRA, C. R.; SENEDA, M. M. Cryosurvival and pregnancy rates after exposure of IVF-derived Bos indicus embryos to forskolin before vitrification. Theriogenology, Stoneham, v. 80, n. 4, p. 372-377, 2013.

SANTOS, A. N.; AUGUSTIN, R.; LAZZARI, G.; GALLI, C.; SREENAN, J. M.; FISCHER, B. The insulindependent glucose transporter isoform 4 Is expressed in bovine blastocysts. Biochemical and Biophysical Research Communications, Orlando, v. 271, n. 3, p. 753$760,2000$.

SASTRE, D.; COSTA, N. N.; DE AS, A. L.; CONCEICAO, S. D.; CHIARATTI, M. R.; ADONA, P. R.; GUEMRA, S.; MEIRELLES, F. V.; SANTOS, S.; SENA, L.; OHASHI, O. M.; SANTOS, E. J.; MIRANDA, M. S. Expression of PLIN2 and PLIN3 during oocyte maturation and early embryo development in cattle. Theriogenology, Stoneham, v. 81, n. 2, p. 326-331, 2014.
SOMFAI, T.; KANEDA, M.; AKAGI, S.; WATANABE, S.; HARAGUCHI, S.; MIZUTANI, E.; DANGNGUYEN, T. Q.; GESHI, M.; KIKUCHI, K.; NAGAI, T. Enhancement of lipid metabolism with l-carnitine during in vitro maturation improves nuclear maturation and cleavage ability of follicular porcine oocytes. Reproduction, Fertility and Development, Melbourne, v. 23, n. 7, p. 912-920, 2011.

SOUZA, D. K.; SALlES, L. P.; ROSA E SILVA, A. A. M. Aspects of energetic substrate metabolism of in vitro and in vivo bovine embryos. Brazilian Journal of Medical and Biological Research, Ribeirão Preto, v. 48, n. 3, p. 191-197, 2015.

SPRICIGO, J. F. W.; DIÓGENES, M. N.; LEME, L. O.; GUIMARÃES, A. L.; MUTERLLE, C. V.; SILVA, B. D. M.; SOLÀ-ORIOL, D.; PIVATO, I.; SILVA, L. P.; DODE, M. A. N. Effects of different maturation systems on bovine oocyte quality, plasma membrane phospholipid composition and resistance to vitrification and warming. Plos One, San Francisco, v. 10, n. 6, p. 1-11, 2015.

SPRICIGO, J. F. W.; MORAIS, K.; FERREIRA, A. R.; MACHADO, G. M.; GOMES, A. C.; RUMPF, R.; FRANCO, M. M.; DODE, M. A. Vitrification of bovine oocytes at different meiotic stages using the Cryotop method: assessment of morphological, molecular and functional patterns. Cryobiology, San Diego, v. 69, n. 2, p. 256-265, 2014.

STINSHOFF, H.; WILKENING, S.; HANSTEDT, A.; BOLLWEIN, H., WRENZYCKI, C. Dimethylsulfoxide and conjugated linoleic acids affect bovine embryo development in vitro. Reproduction Fertility and Development, Melbourne, v. 26, n. 4, p. 502-510, 2014.

STURMEY, R. G.; BERMEJO-ALVAREZ, P.; GUTIERREZ-ADAN, A.; RIZOS, D.; LEESE, H. J.; LONERGAN, P. Amino acid metabolism of bovine blastocysts: a biomarker of sex and viability. Molecular Reproduction and Development, New York, v. 77, n. 3, p. 285-296, 2010.

STURMEY, R. G.; REIS, A.; LEESE, H. J.; MCEVOY, T. G. Role of fatty acids in energy provision during oocyte maturation and early embryo development. Reproduction in Domestic Animals, Berlin, v. 44, n. 3, p. 50-58, 2009.

SUDANO, M. J.; PASCHOAL, D. M.; MAZIERO, R. R. D.; RASCADO, T. S.; GUASTALI, M. D.; CROCOMO, L. F.; MAGALHÃES, L. C. O.; MONTEIRO, B. A.; MARTINS JUNIOR, A.; MACHADO, R.; LANDIMALVARENGA, F. D. C. Improving postcryopreservation survival capacity: an embryo-focused approach. Animal Reproduction, Belo Horizonte, v. 10, n. 3, p. 160-167, 2013. 
SUDANO, M. J.; PASCHOAL, D. M.; RASCADO, T. S.; MAGALHÃES, L. C.; CROCOMO, L. F.; LIMANETO, J. F. de; LANDIM-ALVARENGA, F. Lipid content and apoptosis of in vitro-produced bovine embryos as determinants of susceptibility to vitrification. Theriogenology, Stoneham, v. 75, n. 7, p. 1211-1220, 2011.

SUDANO, M. J.; RASCADO, T. S. D.; TATA, A.; BELAZ, K. R. A.; SANTOS, V. G.; VALENTE, R. S.; MESQUITA, F. S.; FERREIRA, C. R.; ARAÚJO, J. P.; EBERLIN, M. N.; LANDIM-ALVARENGA, F. D. C. Lipidome signatures in early bovine embryo development. Theriogenology, Stoneham, v. 86, n. 2, p. 472-484, 2016.

SUDANO, M. J.; SANTOS, V. G.; TATA, A.; FERREIRA, C. R.; PASCHOAL, D. M.; MACHADO, R.; BURATINI, J.; EBERLIN, M. N.; LANDIM-ALVARENGA, F. D. Phosphatidylcholine and sphingomyelin profiles vary in Bos taurus indicus and Bos taurus taurus in vitro- and in vivo-produced blastocysts. Biology of Reproduction, Champaign, v. 87, n. 6, p. 1-11, 2012.

SUTTON-MCDOWALL, M. L.; FEIL, D.; ROBKER, R. L.; THOMPSON, J. G.; DUNNING, K. R. Utilization of endogenous fatty acid stores for energy production in bovine pre-implantation embryos. Theriogenology, Stoneham, v. 77, n. 8, p. 1632-1641, 2012.

TAKAHASHI, T.; INABA, Y.; SOMFAI, T.; KANEDA, M.; GESHI, M.; NAGAI, T.; MANABE, N. Supplementation of culture medium with L-carnitine improves development and cryotolerance of bovine embryos produced in vitro. Reproduction, Fertility and Development, Melbourne, v. 25, n. 4, p. 589-599, 2013.
TERPSTRA, A. H.; BEYNEN, A. C.; EVERTS, H.; KOCSIS, S.; KATAN, M. B.; ZOCK, P. L. The decrease in body fat in mice fed conjugated linoleic acid is due to increases in energy expenditure and energy loss in the excreta. The Journal of Nutrition, Rockville, v. 132, n. 5, p. 940-945, 2002.

THOMPSON, J. G. In vitro culture and embryo metabolism of cattle and sheep embryos - a decade of achievement. Animal Reproduction Science, Amsterdam, v. 60-61, (não tem número), p. 263-275, 2000.

VANCE, D. E.; VANCE, J. E. Biochemistry of lipids, lipoproteins and membranes. $5^{\text {th }}$ ed. New York: Elsevier Science, 2008. 624 p.

WEST, D. B.; BLOHM, F. Y.; TRUETT, A. A.; DELANY, J. P. Conjugated linoleic acid persistently increases total energy expenditure in AKR/J mice without increasing uncoupling protein gene expression. The Journal of Nutrition, Rockville, v. 130, n. 10, p. 2471-2477, 2000.

YAMANAKA, M.; HASHIMOTO, S.; AMO, A.; ITOSASAKI, T.; ABE, H.; MORIMOTO, Y. Developmental assessment of human vitrified-warmed blastocysts based on oxygen consumption. Human Reproduction, Oxford, v. 26, n. 12, p. 1-6, 2011.

YANG, X.; WU, L. L.; CHURA, L. R.; LIANG, X.; LANE, M.; NORMAN, R. J.; ROBKER, R. L. Exposure to lipid-rich follicular fluid is associated with endoplasmic reticulum stress and impaired oocyte maturation in cumulus-oocyte complexes. Fertility and Sterility, Birmingham, v. 97, n. 6, p. 1438-1443, 2012.

YE, J.; LI, J.; YU, Y.; WEI, Q.; DENG, W.; YU, L. L-carnitine attenuates oxidant injury in HK-2 cells via ROS-mitochondria pathway. Regulatory Peptides, Amsterdam, v. 161, n. 1-3, p. 58-66, 2010. 
